\title{
Determination of Lead in Water Using Amberlite XAD-2 Functionalized With Xylenol Orange Resin as Column Material for On-line Flow Injection- Flame Atomic Absorption Spectrometry Analysis
}

\author{
Reena Saxena $^{a *}$, Suneeti Saxena ${ }^{b}$, and Praveen Sarojam ${ }^{c}$ \\ a,b Department of Chemistry, Kirorimal College, University of Delhi, Delhi -110007, India \\ c Global Application Specialist, AA/ICP, PerkinElmer, Inc., Thane - 400607, India
}

\section{INTRODUCTION}

The analytical monitoring of heavy metals (lead, cadmium, zinc, etc.) in different environmental samples such as industrial water and wastewater is an important issue. Lead is one of the most toxic metals, which can be detected in practically all phases of the inert environment and in all biological systems. Lead is extensively used in storage batteries, solders, cable sheaths, pigments, anti-knock products, and radiation shields (1). According to Australian Drinking Water Guidelines, the maximum permissible limit of lead in water is $0.01 \mathrm{mg} \mathrm{L}^{-1}(2)$ and industrial effluent discharges must limit the lead content to less than $100 \mu \mathrm{g} \mathrm{L} \mathrm{L}^{-1}$ (as per Indian Standards) (3). The determination of lead in biological material, such as blood and tissues, provides an important basis for the diagnosis of clinical disorders, intoxication, and for monitoring environmental pollution. Even at very low concentrations, lead is toxic to animals and humans. As the limits for lead encountered in environmental samples are very low, one needs very sensitive analytical techniques [i.e., electrothermal atomic absorption spectrometry (ETAAS) or inductively coupled plasma mass spectrometry (ICP-MS)] to perform these analyses. Inductively coupled plasma optical emission spectrometry (ICP-OES) and flame atomic absorption spectrometry (FAAS) are

\footnotetext{
* Corresponding author.

E-mail: reenasax@botmail.com
}

\section{ABSTRACT}

A solid phase extraction (SPE) method combined with flow injection (FI) on-line flame atomic absorption spectrometry (FAAS) for the determination of lead in water samples is presented. Amberlite XAD-2, functionalized with xylenol orange resin, was synthesized by covalent coupling of the ligand with the copolymer through an azo group. A minicolumn packed with this resin was connected to the automated on-line preconcentration system. Elution of the metal ions from the minicolumn was performed using $0.1 \mathrm{~mol} \mathrm{~L}^{-1}$ nitric acid solution. The calibration graph obtained was linear over the concentration range of $0-250 \mu \mathrm{g} \mathrm{L}^{-1}$. The sorption capacity of the functionalized resin was found to be $210 \mu \mathrm{mol} \mathrm{g} \mathrm{g}^{-1}$ of dry resin.

A detection limit of $1.058 \mu \mathrm{g} \mathrm{L} \mathrm{L}^{-1}$ was achieved at a sample throughput of $36 \mathrm{~h}^{-1}$. An enrichment factor (EF) of 22 was obtained over conventional flame AAS analysis. Spike recovery studies in water samples were performed using a NIST certified $\mathrm{Pb}$ (II) nitrate solution to confirm the accuracy of the proposed preconcentration procedure.
\end{abstract}

not sensitive enough for some determinations and hence may require the use of a preconcentration step in order to reach an appropriate detection level.

Flame atomic spectrometry is one of the most extensively used analytical techniques for trace element determination with adequate precision and accuracy. However, there is some limitation to determine trace heavy metals in environmental samples due to the method's insufficient detection power or matrix interferences. Online flow injection (FI) solid phase extraction (SPE) has been shown to be efficient and effective in improving the sensitivity and selectivity of FAAS. Moreover, on-line SPE has some other advantages: easy recovery of the solid phase, high sample throughput, and high preconcentration factors. Hence, preconcentration coupled to FAAS is often used as it offers higher sensitivity, selectivity, better precision, and accuracy. Conventional off-line preconcentration procedures, although effective, are usually time-consuming and tedious, require large quantities of sample and reagents, and result in contamination and analyte loss (4). On the other hand, flow injection (FI) methods provide an opportunity to avoid contamination and large reagent consumption by working with closed systems. In addition, FI methods offer higher sample throughput and much better precision and accuracy in comparison to off-line methods $(5,6)$.

There is a critical need for the preconcentration and separation of trace metals from matrices prior to their determination due to their frequent presence in environmental samples and cause for higher matrix interferences. Preconcentration or enrichment of metal ions has been achieved using chelating resins. Development of chelating materials for solid phase extraction 
has gained special attention. Chelating resins possess various advantages which include a high degree of selectivity by controlling the $\mathrm{pH}$, good metal loading capacity, and enhanced hydrophilicity (7). Chelating ligands have been functionalized in materials such as silica gel (8), polyurethane foam (9), cellulose (10), and styrene-divinylbenzene copolymer, commercially available as Amberlite XAD resin series. Amberlite XAD resins are widely used to develop chelating materials for preconcentration procedures due to their good physical and chemical properties including porosity, high surface area, durability, and purity. Many ligands, such as 1,8-dihydroxyanthraquinone (11), $\beta$-nitroso $\alpha$-naphthol (12), salicylic acid (13), chromotropic acid (14), pyrocatechol (15), o-amino benzoic acid (16), 2-(methylthio) aniline (17), and 3,4-dihydroxybenzoic acid (18), were covalently coupled with a polymer backbone through an azo $(-\mathrm{N}=\mathrm{N}-)$, ethylene $\left(\mathrm{CH}_{2}\right)$, or other groups. The choice of a complexing ligand is of great importance since it directly influences the selectivity of the sorbent. In addition, the coordination geometry and the coordination of the metal ion, together with charge and the size of the ion, play an important role in obtaining a selective sorbent. For this study, xylenol orange (19-21) was chosen as the chelating agent due to its multidentate nature.

This work aims (a) to synthesize xylenol orange functionalized Amberlite XAD-2 resin to be used as a solid phase extractor and (b) to develop an on-line preconcentration method for lead determination in water samples using flow injection (FI) with flame atomic absorption spectrometry (FAAS) as a detection method (Figure 1).

\section{EXPERIMENTAL}

\section{Instrumentation}

A PerkinElmer (Shelton, CT, USA) Model AAnalyst ${ }^{\mathrm{TM}} 400$ flame atomic absorption spectrometer, coupled with the FIAS ${ }^{\text {TM }} 400$ flow injection system, was used for the automatic processing of the method and operated in the preconcentration mode. The whole system was controlled by a personal computer and Winlab32 ${ }^{\mathrm{TM}}$ (Version 6.5.0.0266) application software. Figure1 illustrates the on-line flow injection preconcentration system coupled with FAAS. The FIAS 400 preconcentration system comprises two peristaltic pumps, two positional valves, and a preconcentration column. Two Tygon ${ }^{\circledR}$ R3607 red-red pump tubes (i.d.1.14 mm) were applied for both pumps in most of the experiments. The $\mathrm{pH}$ measurements were made with a Model LI614 $\mathrm{pH}$ meter (Elico Ltd., India). An IR spectrum was recorded on a PerkinElmer Model Spectrum RX-1. CHNS was carried out on a Model Varo EL-III Elementor. Thermal analysis was performed with a PerkinElmer Model Diamond DSC.

\section{Standard Solutions and Reagents}

A $1000 \mathrm{mg} \mathrm{L}^{-1}$ stock solution of $\mathrm{Pb}$ (II) was prepared from analytical reagent-grade $\mathrm{Pb}$ (II) nitrate in doubly distilled water obtained from a double distillation unit and standardized titrimetically with EDTA before use. Standard solutions were prepared by dilution of the stock solutions with doubly distilled water. The $\mathrm{pH}$ adjustments were made with $0.1 \mathrm{M} \mathrm{HCl}, 0.1 \mathrm{M} \mathrm{NaOH}$, $0.1 \mathrm{M}$ acetic acid-acetate buffer (pH 4 and 5), $0.1 \mathrm{M}$ phosphate buffer ( $\mathrm{pH} 6$ and 7), and $0.1 \mathrm{M}$ ammonia-ammonium chloride buffer (pH 8 and 9).

All laboratory glassware was kept overnight in a $10 \%(\mathrm{v} / \mathrm{v})$ nitric acid solution and washed before use with doubly distilled water. The Amberlite XAD-2 resin (Sigma-Aldrich) has a surface area of approximately $300 \mathrm{~m}^{2} / \mathrm{g}$, moisture holding capacity of 54-60\%, particle size of 20-60 mesh, pore diameter of $90 \AA$ (mean pore size), and a pore volume of $0.65 \mathrm{~mL} / \mathrm{g}$. Xylenol orange used was of analytical reagent grade. All analytical

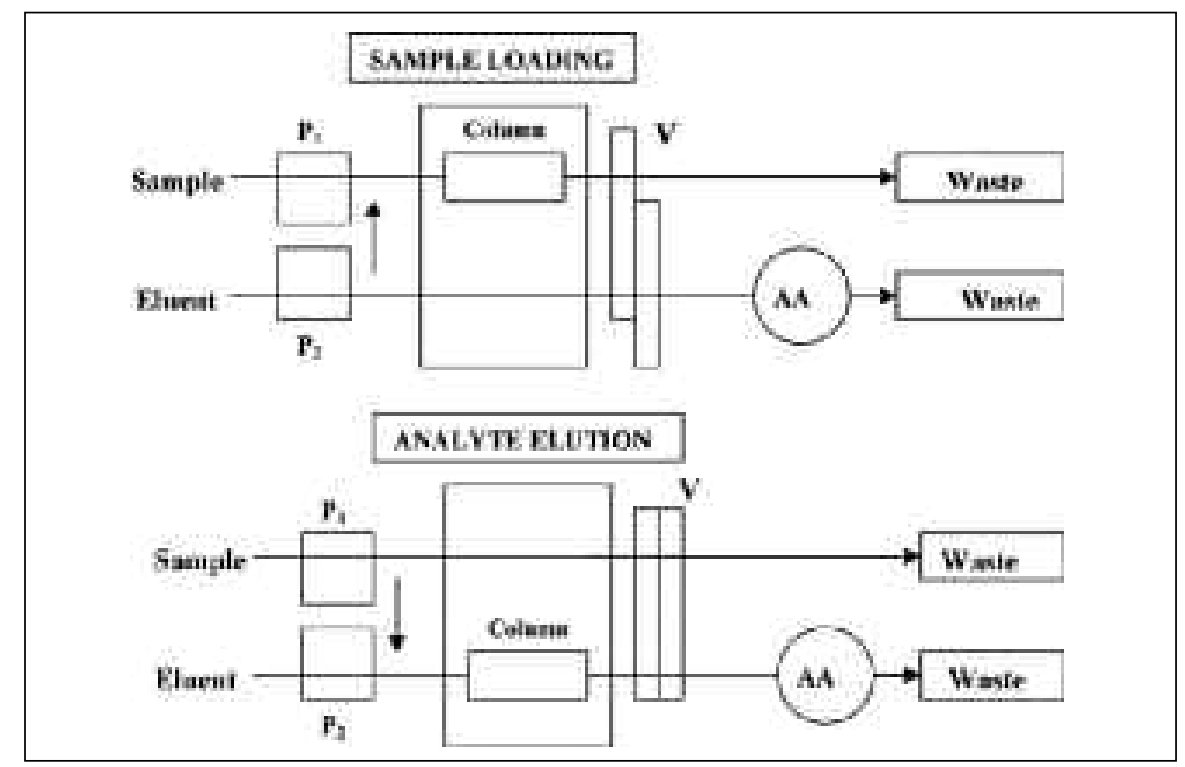

Fig. 1. Schematic of the FAS 400 flow injection preconcentration system: Valve positions (1) for sorption and (2) for elution step (4). 
reagents were procured form either E. Merck (Darmstadt, Germany) or Thomas Baker (India). Certified $\mathrm{Pb}$ (II) nitrate solution, traceable to NIST, was procured from E. Merck. The water samples were collected from Noida, U.P., and from Yamuna water in Delhi, India.

\section{Synthesis of Amberlite XAD-2 Functionalized with Xylenol Orange (AXAD 2-XO) Chelating Resin}

$5.0 \mathrm{~g}$ of Amberlite XAD-2 was stirred with a nitrating mixture of $10 \mathrm{~mL}$ of concentrated $\mathrm{HNO}_{3}$ and $25 \mathrm{~mL}$ of concentrated $\mathrm{H}_{2} \mathrm{SO}_{4}$ on a hot plate with a magnetic stirrer at $60{ }^{\circ} \mathrm{C}$ for 30 minutes. The reaction mixture was poured into ice water. The nitrated resin was filtered, repeatedly washed with water until free from acid, then reduced to the nitro-derivative with $40 \mathrm{~g}$ of $\mathrm{SnCl}_{2}$, $45 \mathrm{~mL}$ of concentrated $\mathrm{HCl}$, and $50 \mathrm{~mL}$ of ethanol by refluxing for 10 hours at $90^{\circ} \mathrm{C}$. The amino polymer was filtered off, washed with water and $2 \mathrm{M} \mathrm{NaOH}$ which released the free amino polymer. The amino polymer was treated with $2 \mathrm{M} \mathrm{HCl}$, washed with water to remove excess $\mathrm{HCl}$, suspended in ice water, and mixed with $1 \mathrm{M} \mathrm{HCl}$ and $1 \mathrm{M} \mathrm{NaNO}$, solution (added in aliquots of $1 \mathrm{~mL}$ ) until the reaction mixture began to give a permanent blue color with starch iodide paper. The diazotized polymer was filtered, washed with cold water, and reacted with xylenol orange at $0-3{ }^{\circ} \mathrm{C}$ for 24 hours. The brown beads were filtered and washed with water (22-23). The Amberlite XAD-2-Xylenol Orange was synthesized by the reactions as shown in schematic of Figure 2.

\section{Preparation of Mini-column}

A $140 \mathrm{mg}$ of synthesized AXAD $2-\mathrm{XO}$ resin was filled into a homemade glass mini-column $(30 \times 3.0 \mathrm{~mm}$ i.d.), plugged with a small portion of glass wool at both ends. Before use, $0.5 \mathrm{~mol} \mathrm{~L}^{-1} \mathrm{HNO}_{3}$ solution and doubly distilled water were passed through the column in order to clean and condition it. Then, the column was conditioned to the desired $\mathrm{pH}$ with a buffer solution. The column had a constant performance during all experiments, and there was no need for any regeneration or repacking.

\section{Procedure for On-line Precon- centration and Determination of $\mathbf{P b}$}

The sample solution (adjusted to $\mathrm{pH}$ 4-5) was pumped at the rate of $5 \mathrm{~mL} \mathrm{~min}^{-1}$ through pump P1 (Figure 1) for 60 seconds during the preconcentration mode. The enriched $\mathrm{Pb}$ (II) was eluted with $0.83 \mathrm{~mL} \mathrm{HNO}_{3}$ at a flow rate of $5 \mathrm{~mL} \mathrm{~min}^{-1}$ for 10 seconds using peristaltic pump P2 and subjected to on-line FAAS determination. The calibrations were linear in the range of $0-250 \mu \mathrm{g} \mathrm{L}^{-1}$ of $\mathrm{Pb}$ (II). In a similar manner, unknown water sample solutions were also subjected to analysis and the $\mathrm{Pb}$ (II) content was determined with reference to the calibration graph. For every standard and sample solution three replicate measurements were carried out.

The FI-FAAS analysis program was controlled by a computer program (24) which includes pre-filling, filling, and loading, and elution steps. Each preconcentration cycle starts with a short loading and elution step performed to fill the tubes. The loading time was 60 seconds for most of the experiments. Elution includes 10 seconds reading time. During the sample loading step, 10 seconds before the valve was moved to the elution position, the signal readings were stabilized with the eluent solution. The flow rate in the elution step was set at $5 \mathrm{~mL} \mathrm{~min}^{-1}$ to ensure the recovery of maximum metal. The absorbance peak was recorded, and its height was the analytical signal.

\section{Analysis of Water Samples}

Water samples were collected from Noida, U.P., in the vicinity of a lead acid battery industrial site and Yamuna water in Delhi. For these samples, the only pre-treatment performed was acidification to $\mathrm{pH}$

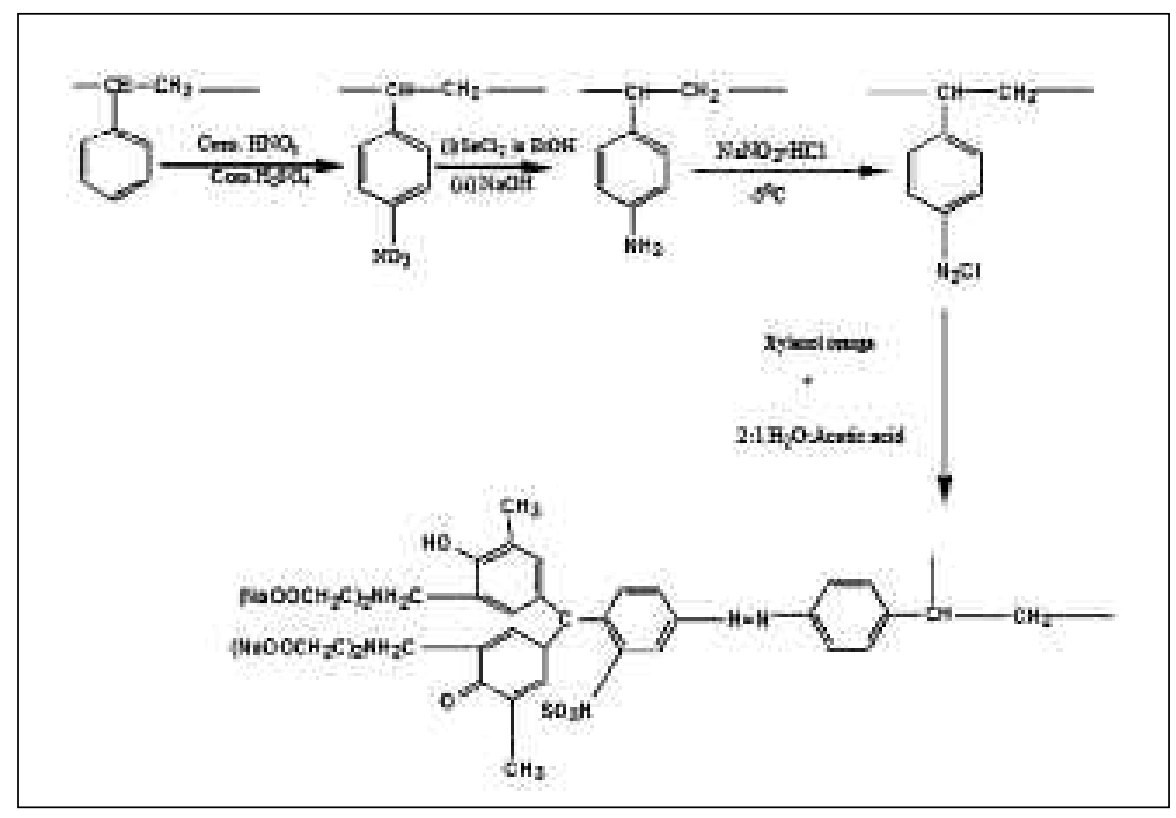

Fig. 2. Schematic of Amberlite XAD-2 functionalized with xylenol orange resin and its proposed structure. 
2.0 with nitric acid, which was performed immediately after collection in order to prevent adsorption of the $\mathrm{Pb}$ (II) ions on the flask walls. The samples were filtered through a $0.45 \mu \mathrm{m}$ pore size filter to remove any suspended particulate matter prior to its preconcentration. After the samples were filtered, the filtrate was adjusted to $\mathrm{pH} 4-5$ by addition of a buffer solution and subjected to on-line FI-FAAS determination using Amberlite XAD-2 xylenol orange resin as column material by following the procedure described above.

\section{RESULTS AND DISCUSSION}

\section{Characterization of Amberlite XAD-2 Functionalized With Xylenol Orange (AXAD-2-XO) Chelating Resin}

The FT-IR spectrum (Figure 3) of the AXAD-2-XO resin exhibited additional bands at: $3448 \mathrm{~cm}^{-1}$ (O-H stretching), $2900 \mathrm{~cm}^{-1}$ (C-H stretching), $1340 \mathrm{~cm}^{-1}\left(-\mathrm{SO}_{3} \mathrm{H}\right), 1047 \mathrm{~cm}^{-1}$ $\left(\mathrm{S}=\mathrm{O}\right.$ stretching), $1628 \mathrm{~cm}^{-1}\left(\mathrm{COO}^{-}\right)$ and $1416 \mathrm{~cm}^{-1}(-\mathrm{N}=\mathrm{N}-)$, which did not appear in the IR spectrum of Amberlite XAD-2. This supported the loading of xylenol orange onto Amberlite XAD-2 with diazotized coupling.

The thermogravimetric analysis (TGA) curve of freshly prepared AXAD-2-XO resin showed a very slow but steady weight loss up to $500{ }^{\circ} \mathrm{C}$. The observed weight loss is $2.3 \%$, up to $120^{\circ} \mathrm{C}$. This is due to physisorbed water on the resin,

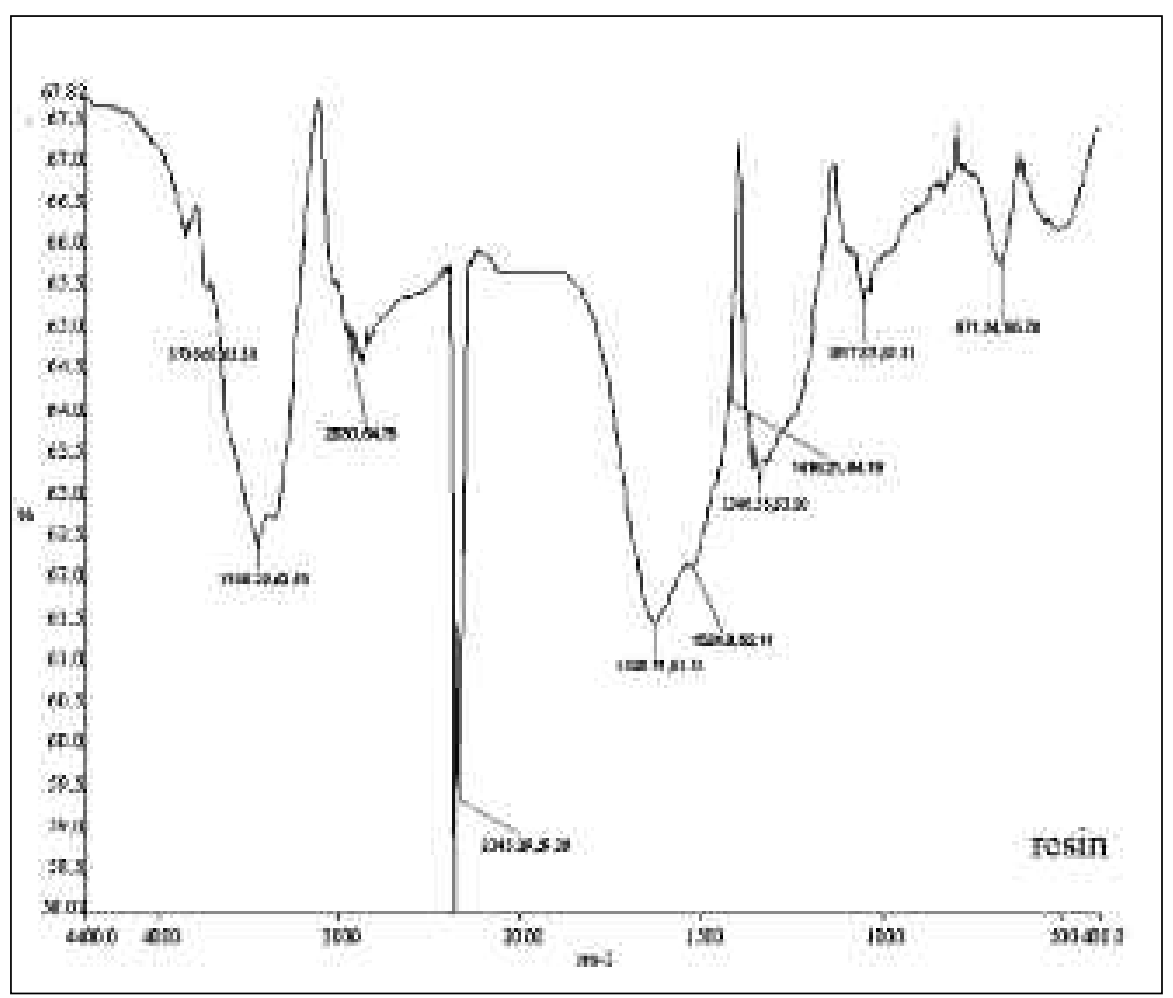

Fig. 3. Infrared spectra of Amberlite XAD-2 functionalized with xylenol orange.

which supported the presence of one water molecule per repeat unit of chelating resin. It is reasonable to assume that with each ring one dye molecule is covalently bonded through an azo group. Most probably it occupies a position para to the $-\mathrm{CH}-\mathrm{CH}_{2}-$ group, owing to electronic effects and steric reasons.

The CHN elemental analysis provides a means for the rapid determination of carbon, hydrogen, and nitrogen in organic matrices and other types of materials. The $\mathrm{C}, \mathrm{H}$, and $\mathrm{N} \%$ in AXAD-2-XO resin was found to be for $\mathrm{C}: 58.99 \%, \mathrm{H}$ : $5.37 \%, \mathrm{~N}: 6.88 \%$, while calculated for $\mathrm{C}_{31} \mathrm{H}_{28} \mathrm{~N}_{2} \mathrm{O}_{13} \mathrm{SNa}_{4} \mathrm{~N}_{2} \mathrm{C}_{8} \mathrm{H}_{7} \cdot 1 \mathrm{H}_{2} \mathrm{O}$ it shows for C: $57.28 \%, \mathrm{H}: 4.53 \%$, $\mathrm{N}: 6.85 \%$. It further confirmed one water molecule per repeat unit of chelating resin.

\section{Optimization of Experimental Parameters for Enrichment of Pb from Dilute Aqueous Solutions}

The preconcentration efficiency of AXAD-2-XO resin was tested with $200 \mu \mathrm{g}$ of lead present in $50 \mathrm{~mL}$ of sample by following the procedure described in the Procedure section.

\section{Influence of pH on FI On-line Preconcentration of $\mathbf{P b}$}

Optimization of the $\mathrm{pH}$ for the sorption of $\mathrm{Pb}$ (II) on a resin column was carried out by a set of solutions, each containing $0.2 \mathrm{mg} \mathrm{L}^{-1}$ of $\mathrm{Pb}$ (II), with a loading or preconcentration time of 1 minute. The $\mathrm{pH}$ of the solutions of the set was adjusted to different values in the range $2.0-11.0$, the retained $\mathrm{Pb}$ (II) ions were eluted with $0.1 \mathrm{~mol} \mathrm{~L}^{-1}$ $\mathrm{HNO}_{3}$, and determined in the eluent by FAAS. The enrichment of the $\mathrm{Pb}$ (II) from these solutions was studied by the recommended column procedure, and the optimum $\mathrm{pH}$ range established is listed later in Table I. The absorbance versus $\mathrm{pH}$ graph was constant over the $\mathrm{pH}$ range 4-5 (Figure 4 ). The results 
showed that the $\mathrm{Pb}$ metal ion was completely adsorbed on the adsorbent over this range.

As can be seen from Figure 4 , increasing the $\mathrm{pH}$ led to an increase in the amount of metal ion adsorbed, while at a high $\mathrm{pH}$ it decreases. This indicates that the adsorption process involved the release of $\mathrm{H}^{+}$ions to allow the firm complexation of metal ions to the AXAD-2-XO resin. The reaction scheme was as follows:

$$
\begin{aligned}
& \mathrm{M}^{2+}+2 \text { Xylenol Orange } \rightarrow \\
& \mathrm{M} \text { (Xylenol Orange })_{2}+2 \mathrm{H}^{+}
\end{aligned}
$$

\section{Effect of Eluent Concentration}

The effect of eluent on $\mathrm{Pb}$ (II) desorption efficiency was investigated in the range of $0.05-0.3 \mathrm{~mol} \mathrm{~L}^{-1}$. The optimum flow rate of $5 \mathrm{~mL} \mathrm{~min}^{-1}$ nitric acid was found to be the most suitable for stripping off the bound metal ions. The concentration of this acid solution and the volume for desorption of the metal ions from the AXAD-2-XO column was optimized by eluting the column with $0.1 \mathrm{M} \mathrm{HNO}_{3}$, while the elution time was fixed at 10 seconds in order to ensure the complete elution of the adsorbed $\mathrm{Pb}$ (II) ions. The results in Figure 5 show that with an increase in the nitric acid concentration up to $0.1 \mathrm{M}$, the absorbance increases, and then decreases at higher concentrations. So, $0.1 \mathrm{M} \mathrm{HNO}_{3}$ was found suitable for the quantitative recovery of the $\mathrm{Pb}$ (II) ions.

\section{Effect of Sample and Eluent Flow Rate}

The effect of sample flow rate on the sorption of $\mathrm{Pb}$ (II) was investigated. The results showed that the flow rate had a good influence on the sorption of lead. The degree of metal ion sorption on a column packed with AXAD-2-XO resin was studied at various flow rates of the metal ion solution using the peristaltic pump P1 of FIAS-400. The optimum flow rate for loading

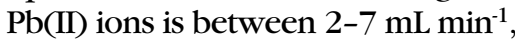
while the volume of the sample remains the same. The quantitative recoveries of the metal ions were obtained with a flow rate of $5 \mathrm{~mL}$ $\mathrm{min}^{-1}$. At higher flow rates, back pressure is produced by the minicolumn and the analytical signal decreases owing to the short residence time of the ions, which resulted in an incomplete retention. On the other hand, low flow rates decrease sample throughput, result-

\section{Atomic Apectroscopy \\ $\bigcup$ Vol. 33(3), May/June 2012}

ing in a long analysis time. In order to improve the analytical efficiency, $5 \mathrm{~mL} \mathrm{~min}^{-1}$ was chosen as the optimum loading rate for the $\mathrm{Pb}$ (II) ions (Figure 6).

The eluent flow rate is an equally important parameter. The effect of flow rate of the eluent nitric acid was studied in the range of 2.0-7.0 mL min ${ }^{-1}$. The results obtained showed that maximum absorbance was achieved at the flow rate of $5.0 \mathrm{~mL} \mathrm{~min}^{-1}$ for $0.2 \mathrm{mg} \mathrm{L}^{-1} \mathrm{~Pb}$ (Figure 7). At this flow rate, the necessary elution time was 10 seconds for complete elution. The eluent was pumped into the column using peristaltic pump P2 of the FIAS-400 system.

\section{Total Sorption Capacity}

The degree of metal sorption at optimum $\mathrm{pH}$ values was determined using the batch equilibration technique. A $50 \mathrm{~mL}$ sample solution containing $100 \mathrm{mg} \mathrm{L}^{-1} \mathrm{~Pb}$ (II) was taken in a glass-stoppered bottle. The $\mathrm{pH}$ was adjusted within the $4.0-5.0$ range with $0.1 \mathrm{M}$ acetic acid-acetate buffer. Then, $0.1 \mathrm{~g}$ of AXAD-2-XO resin was added to the solution and the mixture shaken for 6 hours. The quantitative uptake of

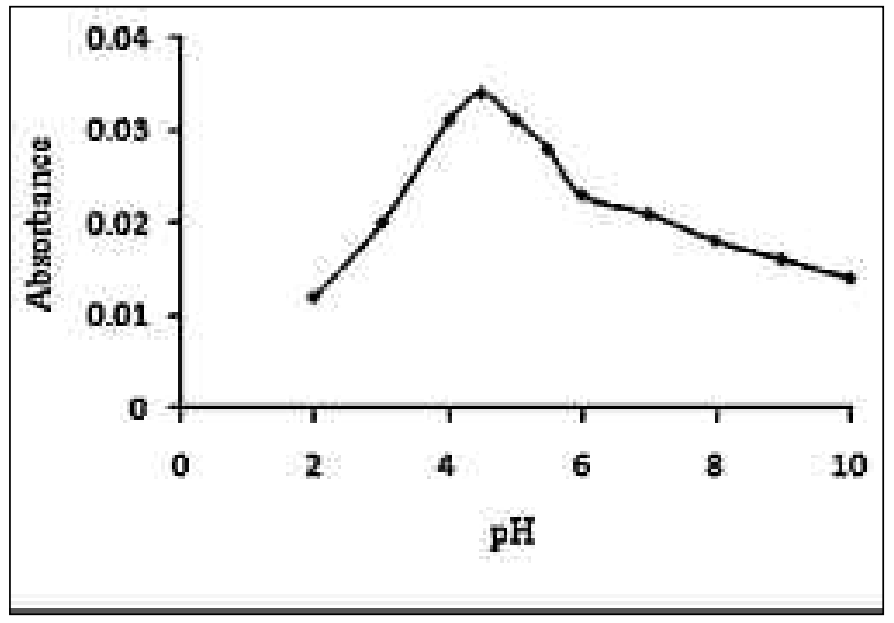

Fig. 4. Effect of $\mathrm{pH}$ on the absorbance of $\mathrm{Pb}(\mathrm{II})$ ions. Conditions: Preconcentration of $5.0 \mathrm{~mL}$ of $0.2 \mathrm{mg} \mathrm{L}^{-1} \mathrm{~Pb}(\mathrm{II})$ with a flow rate of $5.0 \mathrm{~mL} \mathrm{~min}^{-1}$ and elution with $0.1 \mathrm{M} \mathrm{HNO}_{3}$ at

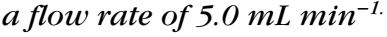

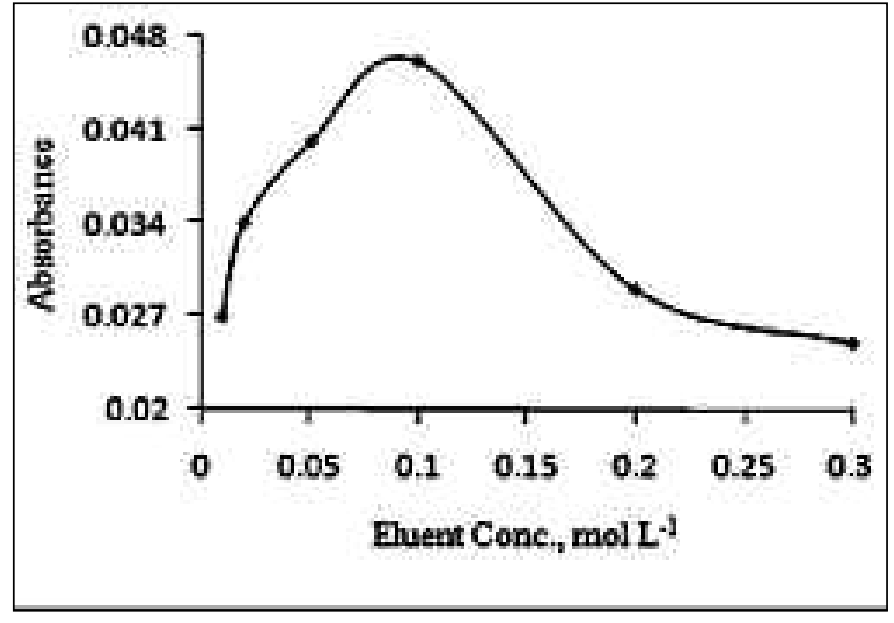

Fig. 5. Effect of eluent concentration on the absorbance of $\mathrm{Pb}(\mathrm{II})$ ions. Conditions: Preconcentration of $5.0 \mathrm{~mL}$ of $0.2 \mathrm{mg} \mathrm{L}^{-1} \mathrm{~Pb}(\mathrm{II})$ buffered at $\mathrm{pH} 4.5$ at a flow rate of $5.0 \mathrm{~mL}$ $\mathrm{min}^{-1}$ and elution with $\mathrm{HNO}_{3}$ at flow rate of $5 \mathrm{~mL} \mathrm{~min}$. 
the metal ion was ascertained by measuring the metal content (by FAAS) in the supernatant liquid and in the eluate obtained by desorbing the metal ion from the resin with $30 \mathrm{~mL}$ of $2.0 \mathrm{M} \mathrm{HNO}_{3}$. The filtrate was aspirated into the flame of the pre-standardized FAAS. The results demonstrated that the sorbent has a sorption capacity of $210 \mu \mathrm{mol} / \mathrm{g}$ of dry resin. The reason for this high value may be due to the high surface area of Amberlite XAD-2 and more chelating sites of xylenol orange (25-28).

\section{Kinetics of Metal Sorption}

The AXAD-2-XO resin (0.5 g) was shaken with $50 \mathrm{~mL}$ solution containing $50 \mathrm{mg} \mathrm{L}^{-1} \mathrm{~Pb}$ (II) for different time intervals $(2,5,10$, $15,20,25,30,40,50,60$ minutes, and 2 hours) under optimum conditions. The $\mathrm{Pb}$ (II) ions, loaded onto the matrix, were stripped with acid of optimum concentration and determined with FAAS. The $\mathrm{Pb}$ (II) concentration in the supernatant solution was also determined with FAAS after appropriate dilution. The variation of sorption as a func-

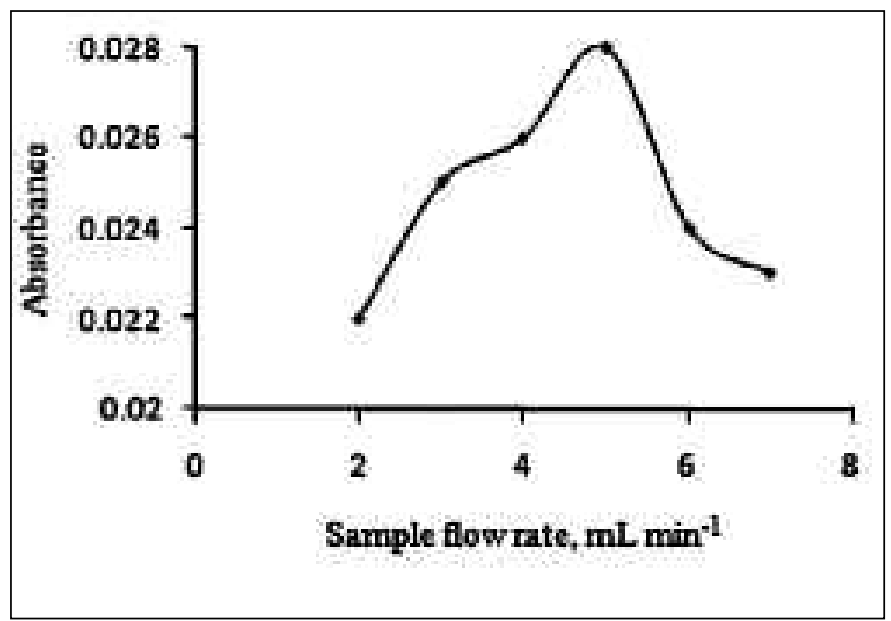

Fig.6. Effect of sample flow rate on the absorbance of Pb(II) ions. Conditions: Preconcentration of $0.2 \mathrm{mg} \mathrm{L}^{-1} \mathrm{~Pb}(\mathrm{II})$ buffered at $\mathrm{pH} 4.5$ and elution with $0.1 \mathrm{M} \mathrm{HNO}_{3}$ at flow rate of $5.0 \mathrm{~mL} \mathrm{~min}^{-1}$.

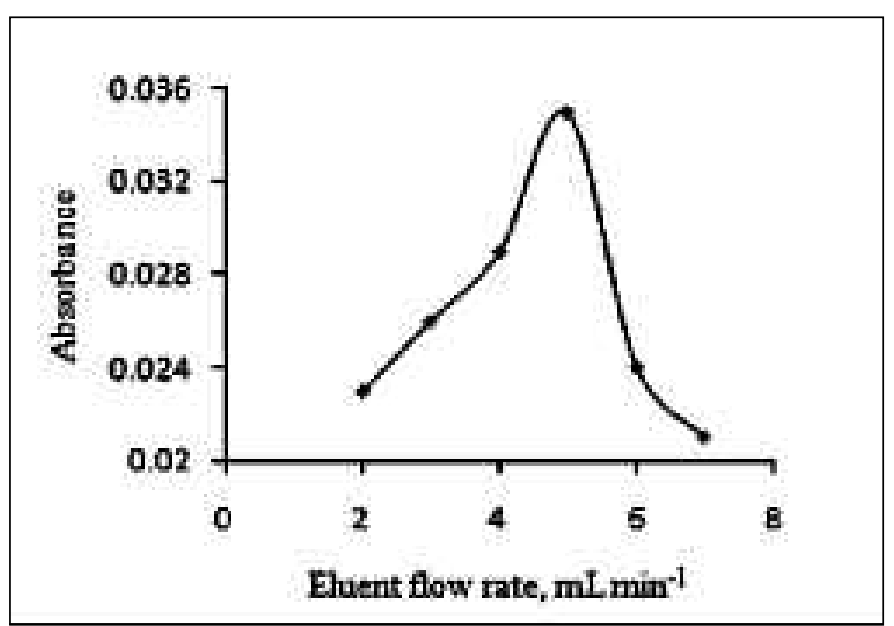

Fig. 7. Effect of eluent flow rate on the absorbance of Pb(II) ions. Conditions: Preconcentration of $5.0 \mathrm{~mL}$ of $0.2 \mathrm{mg} \mathrm{L}^{-1}$ $\mathrm{Pb}$ (II) buffered at $\mathrm{pH} 4.5$ with flow rateof $5.0 \mathrm{~mL} \mathrm{~min}^{-1}$ and elution with $0.1 \mathrm{M} \mathrm{HNO}_{3}$. tion of time for the $\mathrm{Pb}$ (II) ions is shown in Figure 8. A shaking time of 12 minutes was found to be sufficient for more than $50 \%$ sorption of $\mathrm{Pb}$ (II).

\section{Analytical Performance of the On-line Preconcentration Sys- tem for $\mathrm{Pb}$ (II) Determination}

The analytical characteristic data for the on-line preconcentration system for $\mathrm{Pb}(\mathrm{II})$ with AXAD-2-XO resin under the optimal experimental conditions (Table I) are shown in Table II. The calibration graphs were linear at a preconcentration time of 60 seconds and 120 seconds in the range of $0-250 \mu \mathrm{g} \mathrm{L}^{-1}$. The detection limit is defined as the concentration that gives a response equivalent to three times the standard deviation of the blank and was found to be $1.058 \mu \mathrm{g} \mathrm{L}^{-1}$. The enrichment factor (EF) is calculated by the ratio of the slopes of the calibration curves, obtained with and without preconcentration using FAAS $(29,30)$. As the preconcentration time increases, the enrichment factor increases. With a loading time of 60 seconds and 120 seconds, the enrichment factors obtained were 11 and 22, respectively. A sample frequency of $36 \mathrm{~h}^{-1}$ was obtained at a 60 second preconcen-

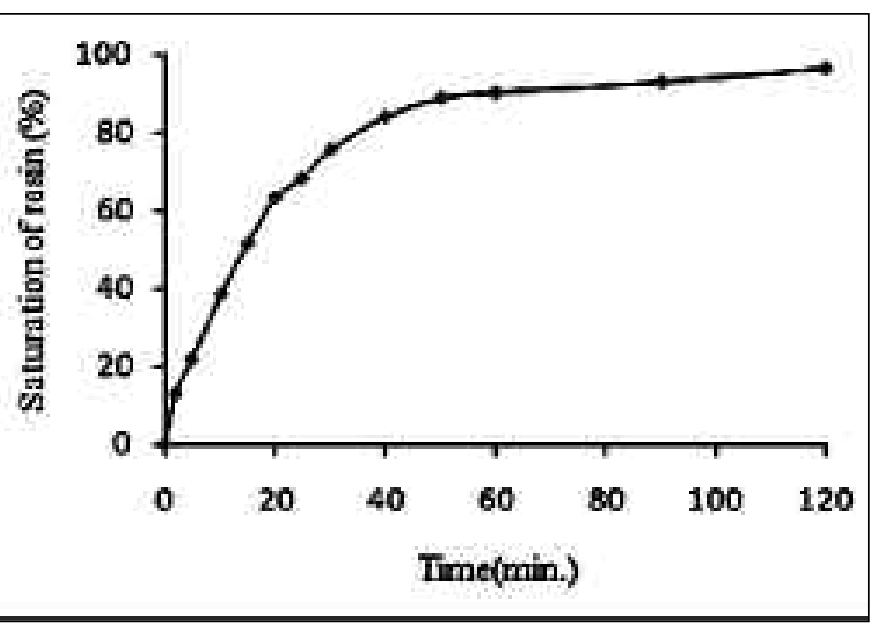

Fig. 8. Kinetics of $\mathrm{Pb}(\mathrm{II})$ sorption on $A X A D-2-X O$ 


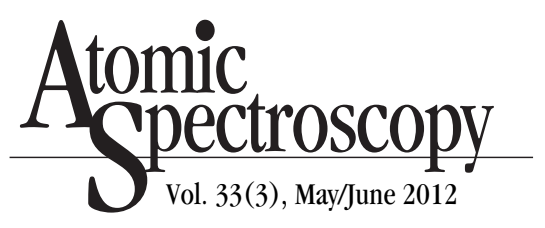

TABLE I

Optimum Conditions of Sorption of $\mathrm{Pb}$ (II) in On-line Preconcentration System

\begin{tabular}{lr}
\hline Parameters & $\begin{array}{r}\text { Optimum } \\
\text { Conditions }\end{array}$ \\
\hline $\begin{array}{l}\text { pH Range } \\
\begin{array}{l}\text { Preconcentration } \\
\text { time (PT) }\end{array}\end{array}$ \\
$\begin{array}{l}\text { Sample flow rate } \\
\text { Sample consumption }\end{array}$ \\
$\begin{array}{l}\text { Eluent flow rate } \\
\text { Acid conc. for } \\
\text { desorption }\end{array}$ \\
$\begin{array}{l}\text { Total sorption } \\
\text { ccapacity }\end{array}$ & $5.0 \mathrm{~mL} \mathrm{~min}$ \\
Sorption kinetics, $\mathrm{t} 1 / 2$ & $0.1 \mathrm{M} \mathrm{HNO}$ \\
\hline
\end{tabular}

tration time. Higher sensitivities can be obtained by modifying the method, i.e., using longer preconcentration times of 120 seconds at the expense of a lower sample throughput of $22 \mathrm{~h}^{-1}$. The precision (RSD, $\mathrm{n}=5$ ) was found to be $1.69 \%$ for $\mathrm{Pb}$ (II) which shows that the SPE elution sequence is highly reproducible.

\section{Effect of Matrix Ions on Preconcentration}

Preconcentration procedures for trace elements in high salt content samples can be strongly affected by the matrix constituents of the sample. This is known as matrix effect. The chloride, nitrate, sulfate, and phosphate ions commonly found in natural water samples have the capability to complex with many metal ions. Therefore, in their presence, the efficiency of the chelating resins to bind metal ions may be hampered, resulting in the reduction of overall enrichment. Thus, the effect of $\mathrm{NaCl}, \mathrm{NaNO}_{3}, \mathrm{Na}_{2} \mathrm{SO}_{4}$, $\mathrm{Na}_{3} \mathrm{PO}_{4}, \mathrm{NaBr}, \mathrm{MgCl}_{2}$, citric acid, tartaric acid, and ascorbic acid on the sorption efficiency of AXAD-2$\mathrm{XO}$ resin for $0.2 \mathrm{mg} \mathrm{L}^{-1} \mathrm{~Pb}$ (II) was studied using the recommended flow injection column method under the optimum conditions.

TABLE II

Analytical Performance of Flow Injection On-line Method for $\mathrm{Pb}$ (II) Determination

\begin{tabular}{lll}
\hline Parameters & \multicolumn{2}{c}{ Optimum Conditions } \\
\hline Preconcentration time (PT) & $60 \mathrm{sec}$ & $120 \mathrm{sec}$ \\
Linear range & $0-250 \mu \mathrm{g} \mathrm{L}^{-1}$ & $0-250 \mu \mathrm{g} \mathrm{L}^{-1}$ \\
Limit of detection & $1.058 \mu \mathrm{g} \mathrm{L}^{-1}$ & - \\
Sample throughput & 36 & 22 \\
Enhancement factor & 11 & 22 \\
Regression Equation (6 standards, & $\mathrm{A}_{60}=0.00167+1.2564\left[\mathrm{~Pb}(\mathrm{II}) / \mathrm{mgL}^{-1}\right]$ \\
with preconcentration) & $\mathrm{A}_{120}=0.00271+2.4678\left[\mathrm{~Pb}(\mathrm{II}) / \mathrm{mgL}^{-1}\right]$ \\
Regression equation(6 standards, & $\mathrm{A}=0.0037+0.11493\left[\mathrm{~Pb}(\mathrm{II}) / \mathrm{mgL}^{-1}\right]$ \\
without preconcentration) & & \\
Correlation coefficient & 0.98352 & 0.99347 \\
Precision (R.S.D.\%) $\mathrm{n}=5$ & $1.69,[\mathrm{~Pb}(\mathrm{II})]=0.2 \mathrm{mg} \mathrm{L}$ \\
\hline
\end{tabular}

The tolerance limits for the electrolytes are given in Table III.

A species is considered to interfere when it lowers the recovery of the metal ions by more than $\pm 5 \%$ compared to the value observed in its absence. In general, the tolerance limits suggested that the common ions and the organic acids like citric acid, tartaric acid, and ascorbic acid ions do not adversely affect sorption on the resin used in this study when present in moderate amounts.

\section{Column Stability and Re-usability}

The repeated cycles of preconcentration and elution of lead with the newly synthesized AXAD-2-XO resin was then studied. The stability of resin was studied in $1.0-5.0 \mathrm{M}$ $\mathrm{HCl} / \mathrm{HNO}_{3}$ acid. The resin was kept in acid for 24 hours and then filtered. The solid was washed with doubly distilled water until free from acid, then air-dried. Then, sorption and desorption were repeated on the same resin bead and the amount of lead eluted was determined. The variation in the results obtained for such analyses was $<2.0 \%$. The capacity of the resin was found to be practically constant and the sorption efficiency was not less than $97 \%$
TABLE III Effects of Matrix Ions on the Recovery of $\mathrm{Pb}$ (II) Ions

\begin{tabular}{ll}
\hline Electrolytes & Tolerance Limit \\
\hline $\mathrm{NaCl}$ & $0.4 \mathrm{~mol} \mathrm{~L}^{-1}$ \\
$\mathrm{Na}_{2} \mathrm{SO}_{4}$ & $0.04 \mathrm{~mol} \mathrm{~L}^{-1}$ \\
$\mathrm{NaNO}_{3}$ & $0.017 \mathrm{~mol} \mathrm{~L}^{-1}$ \\
$\mathrm{Na}_{3} \mathrm{PO}_{4}$ & $0.08 \mathrm{~mol} \mathrm{~L}^{-1}$ \\
$\mathrm{NaBr}$ & $0.02 \mathrm{~mol} \mathrm{~L}^{-1}$ \\
$\mathrm{NaI}$ & $0.1 \mathrm{~mol} \mathrm{~L}^{-1}$ \\
$\mathrm{MgCl}$ & \\
$\mathrm{K}(\mathrm{I})$ & $0.03 \mathrm{~mol} \mathrm{~L}^{-1}$ \\
$\mathrm{~Pb}(\mathrm{II}), \mathrm{Zn}(\mathrm{II})$ & $14 \mathrm{mg} \mathrm{L}^{-1}$ \\
$\mathrm{Fe}(\mathrm{III}), \mathrm{Cu}(\mathrm{II})$ & $5 \mathrm{mg} \mathrm{L}^{-1}$ \\
$\mathrm{Al}(\mathrm{III}), \mathrm{Ca}(\mathrm{II})$ & $10 \mathrm{mg} \mathrm{L}^{-1}$ \\
EDTA & $0.6 \mathrm{mM} \mathrm{L}^{-1}$ \\
Citric acid & $0.1 \mathrm{~mol} \mathrm{~L}^{-1}$ \\
Tartaric acid & $0.2 \mathrm{~mol} \mathrm{~L}^{-1}$ \\
Ascorbic acid & $0.5 \mathrm{~mol} \mathrm{~L}^{-1}$ \\
\hline
\end{tabular}

after being used for $70-80$ cycles. This observation reflects the reusability of the resin.

\section{Analytical Applications}

In order to assess the accuracy and applicability of the modified resin AXAD-2-XO for $\mathrm{Pb}(\mathrm{II})$ ion determination, the recommended procedure was applied to determine $\mathrm{Pb}$ (II) in water. Water samples were collected from two 
different places: the Noida industrial area and the Yamuna river (Delhi). Then $5.0 \mathrm{~mL}$ (sample flow rate of $5.0 \mathrm{~mL} \mathrm{~min}^{-1}$ and sample loading time 60 seconds) of each sample was preconcentrated and analyzed by the proposed method. Since the analyte concentration of the water sample was too low using the direct method, the water samples were spiked and the recoveries studied. The accuracy of the preconcentration procedure was performed by recovery experiments for the spiked sample using certified $\mathrm{Pb}$ (II) nitrate solution traceable to NIST. The results are given in Table IV. It was found that spiking a sample with $10 \mu \mathrm{g} \mathrm{L}^{-1} \mathrm{~Pb}$ (II) gave very good recoveries ranging from 97-98\%.

For comparative purposes, the performance characteristics of the proposed method and other selected on-line SPE preconcentration FAAS methods reported in the literature are given in Table $\mathrm{V}$.

The proposed method shows good sensitivity (detection limit), better precision (RSD), and high sample throughput with a reasonable enhancement factor (EF) over other on-line preconcentration methods.

\section{CONCLUSION}

In the present study, a new, simple, and environmentally friendly solid phase extraction (SPE) technique was developed based on the flow injection (FI) on-line sorbent extraction preconcentration system. In this technique, a minicolumn packed with Amberlite XAD-2 resin, functionalized with xylenol orange, was used for preconcentration of $\mathrm{Pb}$ (II) in water samples prior to the determination of $\mathrm{Pb}$ by flame atomic absorption spectrometry (FAAS). The parameters including $\mathrm{pH}$ of the sample, sample volume, type and volume of eluents, and effect of foreign ions were studied. The determination of $\mathrm{Pb}$ using this method shows good

TABLE IV

Analytical Results for the Determination of $\mathrm{Pb}$ (II) in Water Samples

\begin{tabular}{lccc}
\hline Sample & $\begin{array}{c}\text { Conc. } \\
\text { Determined } \\
\left(\mu \mathrm{g} \mathrm{L}^{-1}\right)\end{array}$ & $\begin{array}{c}\text { Conc. Determined } \\
\text { with } 10 \mu \mathrm{g} \mathrm{L}^{-1} \text { spiked } \\
\mathrm{Pb}(\mathrm{II})\left(\mu \mathrm{g} \mathrm{L}^{-1}\right)\end{array}$ & $\begin{array}{l}\text { Recovery } \\
\text { Noida, U.P, India }\end{array}$ \\
\hline $5.8 \pm 0.16$ & $15.53 \pm 0.21$ & 98 \\
\hline Yamuna, Delhi, India & $8.0 \pm 0.16$ & $17.53 \pm 0.41$ & 97 \\
\hline
\end{tabular}

TABLE V

Comparison of Performance Characteristics Among Selected On-line SPE Methods and the Developed Method for the Pb(II) Determination With FAAS.

\begin{tabular}{|c|c|c|c|c|c|c|c|}
\hline Support & Chelating Agent & Eluent & $\mathrm{EF}$ & $\begin{array}{c}\mathrm{f} \\
\left(\mathrm{h}^{-1}\right)\end{array}$ & $\begin{array}{c}\text { RSD } \\
(\%)\end{array}$ & $\begin{array}{c}\mathrm{DL} \\
\left(\mu \mathrm{g} \mathrm{L}^{-1}\right)\end{array}$ & Ref. \\
\hline $\begin{array}{l}\text { Activated } \\
\text { carbon }\end{array}$ & - & Ethanol & 14 & 9 & $<5$ & 14 & 31 \\
\hline $\begin{array}{l}\text { Carbon nano- } \\
\text { tubes }\end{array}$ & - & $\mathrm{HCl}$ & 15.4 & 25 & - & 1.0 & 32 \\
\hline $\begin{array}{l}\text { Polyurethane } \\
\text { foam }\end{array}$ & $\begin{array}{l}2-\left(6^{\prime}-\text { methyl-2'- }\right. \\
\text { benzothiazolylazo }) \\
\text { chromotropic acid }\end{array}$ & HCl & 20 & 51 & 2.9 & 8.58 & 33 \\
\hline- & $\begin{array}{l}\text { 1-(2-thiazolylazo)- } \\
\text { 2-naphthol (TAN) }\end{array}$ & $\mathrm{HCl}$ & 15.1 & - & - & 4.5 & 34 \\
\hline $\begin{array}{l}\text { Amberlite } \\
\text { XAD-4 }\end{array}$ & $\begin{array}{l}\text { 4-(2 pyridylazo) } \\
\text { Resorcinol }\end{array}$ & $\mathrm{HCl}$ & 9 & 16 & 2.3 & 7.0 & 35 \\
\hline $\begin{array}{l}\text { Amberlite } \\
\text { XAD-2 }\end{array}$ & BTAC & $\mathrm{HCl}$ & 27 & - & $4.4-2.3$ & 3.7 & 36 \\
\hline $\begin{array}{l}\text { Amberlite } \\
\text { XAD-2 }\end{array}$ & Xylenol Orange & $\mathrm{HNO}_{3}$ & 22 & 36 & 1.69 & 1.058 & $\begin{array}{l}\text { This } \\
\text { Work }\end{array}$ \\
\hline
\end{tabular}

EF: enhancement factor; f: sampling frequency; RSD: precision (relative standard deviation); DL: detection limit.

precision and accuracy resulting in a detection limit of $1.058 \mu \mathrm{g} \mathrm{L}^{-1}$ and a sample frequency of $36 \mathrm{~h}^{-1}$. The main advantages of the proposed method are low detection limit, high preconcentration factor, and short analysis time.

The AXAD-2-XO resin has good loading capacity, good re-usability, high selectivity and high stability, and can remain stable in strongly acidic and basic media. This feature provides the advantage of using this resin up to $70-80$ cycles. Spike recovery analysis was performed using certified $\mathrm{Pb}$ (II) nitrate trace- able to NIST to confirm the efficiency of the developed on-line preconcentration method.

\section{ACKNOWLEDGMENT}

The authors are thankful to the Department of Science and Technology, Government of India, New Delhi, India, for financial assistance. Thanks to Prof. A.K. Singh, Head of the Department, Department of Chemistry, Indian Institute of Technology, for giving proper guidance.

Received February 27, 2012. 


\section{Appectroscopy \\ 1 Vol. 33(3), May/June 2012}

\section{REFERENCES}

1. www.epa.gov./safewater (January 2002).

2. E. Rossi, "Low Level Environmental Lead Exposure - A Continuing Challenge". The Clinical biochemist. Reviews/ Australian Association of Clinical Biochemists 29, 63 (2008).

3. Teri Energy Data Directory Yearbook, 2000-2001.

4. R.S. Praveen, G.R.K. Naidu and T. Rao Prasada, Anal. Chim. Acta, 600, 205 (2007).

5. Z. Fang, Flow Injection Separation and Preconcentration, $\mathrm{VCH}$, New York (1993).

6. J. Ruzicka and E.H. Hansen, Flow Injection Analysis, 2nd ed., Wiley, New York (1988)

7. V. A. Lemos and, P. X. Baliza, Talanta 67, 564 (2005)

8. H. F. Maltez, M. A. Vieira, A. S. Ribeiro, A. J. Curtius and E. Carasek, Talanta 74, 586 (2008).

9. W.N.L. Dos Santos, J.L.O. Costa, R.G.O. Araujo, D.J. de Jesus, and A.C.S. Costa, J. Hazard. Mater. 137, 1357 (2006).

10. A. M. Naghmush, K. P. Iska and M. Trojanowicz, Talanta 42, 851 (1995).

11. A. Goswami and A. K. Singh, Talanta 58, 669 (2002).

12. V. A. Lemos, E. S. Santos and E.M. Gama Separ, Purifi. Tech. 56, 212 (2007)

13. R. Saxena, A.K. Singh and D.P.S. Rathore, Analyst 120, 403 (1995).

14. P.K Tewari and A.K. Singh, Talanta 56,735 (2002).

15. V.A. Lemos, E. M.Gama and A. da Silva Lima, Microchim. Acta 153 , 179 (2006)

16. S. D. Cekic, H. Filik and R. Apak, Anal. Chim. Acta 505, 15 (2004).

17. Y. Guo, B. Din, Y. Liu, X. Chang, S. Meng and M. Tian, Anal. Chim. Acta 504, 319 (2004).

18. V.A. Lemos, P.X. Baliza, R.T. Yamaki, M.E. Rocha and A.P.O. Alves, Talanta 61, 675 (2003).
19. Yu. V. Kholin and S. V. Korneev, Russian J. of Appl. Chem. 78, 7 (2005).

20. A. Ali Ensafi and A. Zendegi Shiraz, J. Hazard. Mater. 150, 554 (2008).

21. P. Kumar Tewari and A. Kumar Singh, Fresenius J. Anal Chem 367, 562 (2000).

22. R. Saxena, A. K.Singh and S.S. Sambi, Anal. Chim. Acta 295, 199 (1994).

23. R. Saxena and A. K. Singh, Anal. Chim. Acta 340, 285 (1997).

24. S. Walas, A.Tobiasz, M. Gawin, B. Trzewik, M. Strojny and $\mathrm{H}$. Mrowiec, Talanta 76, 96 (2008).

25. A. Islam, A. Ahmad and A. Laskar Mohammad, Anal. Methods 3, 2041 (2011)

26. M. Kumar, D.P.S. Rathore, and Ajai K.Singh, Talanta 51,187 (2000).

27. G. Venkatesh and Ajai K. Singh, Talanta 67,187 (2005).

28. G. Venkatesh and Ajai K. Singh, Sep. Sc. and Tech. 42, 3429 (2007).

29. S. Zhao, H. Liang, H. Yan, Z. Yan, S. Che, Z. Xiand and C. Miaoxian, Clean- Soil, Air, Water 38, 146 (2010).

30. A.N. Anthemidis, A. George, Zachariadis and J.A. Stratis, Intern, J. Environ. Anal. Chem. 90, 127 (2010).

31. S.P. Quinaia, M.C. E. Rollemberg, J. B. B. Da Silva, Can. J. Anal. Sc. Spec. 51, 225 (2006).

32. X. Zhao, N. Song, Q. Jia and W. Zhou, Microchimica Acta 166, 329 (2009).

33. E.M. Gama, A.D.S. Lima, and V.A. Lemos, J. Hazard. Mater. 136, 757 (2006).

34. E.L.Silva and Paulo dos S.Roldan, J. Hazard. Mater.161,142 (2009).

35. J. Klamtet, N. Suphrom, and C. Wanwat, Mj. Int. J. Sci. Tech. 2, 408 (2008).

36. S.L.C.Ferreiraa, V.A.Lemos, R. E. Santelli, E.Ganzarolli and A. J. Curtius, Microchem. J. 68,41 (2001). 